\title{
The Influence of Local Authorities on the Formation of a System of Motivation of Citizens for a Healthy Lifestyle
}

\author{
Olga Urzha*, Tatyana Evstratova \\ Russian State Social University, 4-1 V. Pika Str., Moscow, 129226, Russia
}

Received August 18, 2021; Revised November 10, 2021; Accepted November 28, 2021

\section{Cite This Paper in the following Citation Styles}

(a): [1] Olga Urzha, Tatyana Evstratova, "The Influence of Local Authorities on the Formation of a System of Motivation of Citizens for a Healthy Lifestyle," Universal Journal of Public Health, Vol. 9, No. 6, pp. 392 - 400, 2021. DOI: 10.13189/ujph.2021.090606.

(b): Olga Urzha, Tatyana Evstratova (2021). The Influence of Local Authorities on the Formation of a System of Motivation of Citizens for a Healthy Lifestyle. Universal Journal of Public Health, 9(6), 392 - 400. DOI: 10.13189/ujph.2021.090606.

Copyright $\bigcirc 2021$ by authors, all rights reserved. Authors agree that this article remains permanently open access under the terms of the Creative Commons Attribution License 4.0 International License

\begin{abstract}
The health of the nation is the key to the successful development of any state. Therefore, taking care of the health of each citizen and creating conditions for its preservation are the key objectives of authorities at all levels. To develop and implement the organizational and methodological measures aimed at solving this problem, it is necessary to create a complex system of measures accounting for the specific features of the country as a whole, its territory, climatic conditions, historical traditions, demographic and economic situation, i.e. to develop a scientific approach to the creation of the National Project of the healthy lifestyle of citizens. The development of the project has to take into consideration the social structure of each municipality, the presence of all age and gender groups, the state of citizens' health and their potential opportunities to engage in particular types of sports, the dynamics and perspective of changes. It is also necessary to take into account the typology of the country's municipalities, i.e. its administrative and territorial structure since Russia is a huge country with extremely diverse specifics of individual territories. In addition, it is necessary to take into consideration the priorities in the choice of mass types of sports for different social groups; providing staffing for physical culture and sports work in the field; developing a system for the promotion of physical culture and sports as an important component of a healthy lifestyle. Of critical importance is also the study of positive practices in this sphere since Russia has a great experience of past and contemporary examples of organizing citizens' healthy lifestyle that have to be
\end{abstract}

generalized and disseminated.

Keywords Formation of a Healthy Lifestyle of the Population, Provision of Physical Culture and Sports Work in Municipalities, Development of Sports Infrastructure at the Place of Residence, Improving the Promotion of Physical Culture and Sports

\section{Introduction}

A strategically important objective of every state is the preservation of the nation's health, the improvement of citizens' life expectancy and ability to work. In the conditions of socio-economic and political transformations in Russia, addressing the problem of improving citizens' physical health and ensuring a healthy lifestyle by means of engaging various social groups of the population in physical culture and sports gains special importance. Success in solving this critical national objective largely depends on the effectiveness of the authorities at all levels in organizing physical culture and sports work with the population and creating all the necessary conditions for it.

On July 21, 2020, the President of the Russian Federation signed Decree No. 474 "On the national development goals of the Russian Federation for the period up to 2030" [1]. The decree specifies the main national objectives of the country's development aimed at 
implementing breakthrough development of the Russian Federation, increasing the country's population, and improving the standard of living of its citizens. One of the first goals is defined as "Population preservation, health, and well-being".

This national goal identifies the following indicators:

- ensuring sustainable growth of the population of the Russian Federation;

- increasing life expectancy to 78 years old;

- increasing the proportion of citizens systematically engaged in physical culture and sports to $70 \%$.

Earlier, on May 7, 2018, the President signed Decree No. 204 "On the national goals and strategic objectives of the development of the Russian Federation for the period up to 2024" [2]. To implement the established objectives, a federal project "Strengthening Public Health" was developed. The project implementation period is from January 1, 2019, to December 31, 2024. One of the first tasks included in the passport of the Federal project is "Formation of a system of motivation of citizens for a healthy lifestyle, including healthy eating and giving up bad habits". For its implementation, normative legal acts and methodological documents concerning the issues of citizens' healthy lifestyle were developed and adopted based on the recommendations of the World Health Organization.

However, with the issuance of Decree No. 474, the previous Decree No. 204 ceased to be in force since much more drastic measures proved to be needed to achieve the goal of "Population preservation, health, and well-being". The forecast of the number and structure of Russia's population are indicative of this. Let us proceed to review these forecasts based on authoritative sources: the Federal State Statistics Service [3], the UN Population Division [4], and the US Census Bureau [5].

\section{Methods}

\subsection{General Description}

The practice of population projections customarily considers several methods. For example, Rosstat calculates three options of the estimated population: low, medium, and high; the UN Population Division has eight options. Let us turn to the so-called average or the most probable variant of prospective estimates. Various prognostic calculations are recommended to be carried out based on this variant of estimation.

It should be noted that in the period under study, the most important trend in the demographic dynamic of Russia is population decline (Table 1), its aging (Table 2), and the reduction of the population in the economically active age (Table 3 ).

The same trend, however, is characteristic of many other countries according to national projections by 2030 .

Table 1. Prospective estimates of Russia's population, million people

\begin{tabular}{|c|c|c|c|c|c|}
\hline \multirow{2}{*}{ Source } & \multicolumn{5}{|c|}{ Year } \\
\cline { 2 - 6 } & $\mathbf{2 0 1 0}$ & $\mathbf{2 0 1 5}$ & $\mathbf{2 0 2 0}$ & $\mathbf{2 0 2 5}$ & $\mathbf{2 0 3 0}$ \\
\hline Rosstat & 141.9 & 142.2 & 141.9 & 140.9 & 139.4 \\
\hline $\begin{array}{c}\text { Rosstat } \\
\text { (not accounting } \\
\text { for migration) }\end{array}$ & 141.9 & 140.7 & 138.9 & 136.1 & 132.8 \\
\hline $\begin{array}{c}\text { UN Population } \\
\text { Division }\end{array}$ & 142.9 & 142.2 & 141.0 & 139.0 & 136.4 \\
\hline $\begin{array}{c}\text { US Census } \\
\text { Bureau }\end{array}$ & 139.4 & 136.0 & 132.2 & 128.2 & 124.1 \\
\hline
\end{tabular}

Russia is predicted to experience a global demographic trend - the aging of the population - by 2030 . The share of people aged 65 and older will increase by $60 \%$, almost every fifth resident of the country will be over 65 years old in 2030. At the same time, Russia will lag behind the developed countries by the level of aging. For example, the proportion of people aged 65 and over will be about $25 \%$ in Germany and almost $30 \%$ in Japan [6]. Such a lag is explained by a relatively high mortality rate and short life expectancy at older ages [7].

In the past two years, because of the coronavirus pandemic sweeping the globe, mortality rates have risen significantly. But that is a topic for another study.

Another unfavorable trend is the reduction of the population in the economically active age group, or the age group able to work. Formally, since the Soviet times, the economically active population includes men aged 16 to 60 years old and women aged 16 to 55 years old, in international practice, these boundaries are wider. In the present, Rosstat considers people aged 15-72 years old as the economically active population [8]. The decline in the number of economically active, working-age population by 2030 can be explained by the sharp decline in the birth rate in the late 1980s and 1990s.

Table 2. The age structure of Russia's population in 2010 and 2030, in \%

\begin{tabular}{|c|c|c|c|c|c|c|}
\hline \multirow{2}{*}{ Source } & \multicolumn{3}{|c|}{$\mathbf{2 0 1 0}$} & \multicolumn{2}{c|}{$\mathbf{2 0 3 0}$} \\
\cline { 2 - 7 } & $\begin{array}{c}\mathbf{0 - 1 4} \\
\text { years old }\end{array}$ & $\begin{array}{c}\mathbf{1 5 - 6 4} \text { years } \\
\text { old }\end{array}$ & $\begin{array}{c}\mathbf{6 5} \text { years old } \\
\text { and older }\end{array}$ & $\begin{array}{c}\mathbf{0}-\mathbf{1 4} \text { years } \\
\text { old }\end{array}$ & $\begin{array}{c}\mathbf{1 5}-\mathbf{6 4} \text { years } \\
\text { old }\end{array}$ & $\begin{array}{c}\mathbf{6 5} \text { years old } \\
\text { and older }\end{array}$ \\
\hline Rosstat & 15.1 & 72.0 & 12.9 & 15.2 & 65.4 & 19.4 \\
\hline $\begin{array}{c}\text { Rosstat } \\
\text { (not accounting for migration) }\end{array}$ & 15.1 & 72.0 & 12.9 & 15.3 & 65.2 & 19.5 \\
\hline UN Population Division & 15.0 & 72.2 & 12.8 & 15.8 & 65.1 & 19.1 \\
\hline US Census Bureau & 15.0 & 71.7 & 13.3 & 14.2 & 64.9 & 20.9 \\
\hline
\end{tabular}


Table 3. Prospective estimates of the population in the economically active age, million people

\begin{tabular}{|c|c|c|c|c|c|}
\hline \multirow{2}{*}{ Source } & \multicolumn{5}{|c|}{ Year } \\
\hline & 2010 & 2015 & 2020 & 2025 & 2030 \\
\hline \multicolumn{6}{|c|}{ All population at the age of $15-64$ years old } \\
\hline Rosstat & 102.2 & 99.8 & 96.0 & 93.0 & 91.1 \\
\hline $\begin{array}{c}\text { Rosstat } \\
\text { (not accounting for } \\
\text { migration) }\end{array}$ & 102.2 & 98.7 & 93.8 & 89.6 & 86.6 \\
\hline UN Population Division & 103.2 & 99.7 & 95.2 & 91.5 & 88.8 \\
\hline US Census Bureau & 100.0 & 95.1 & 89.6 & 84.6 & 80.5 \\
\hline \multicolumn{6}{|c|}{ Men aged $16-59$ years old, women aged $16-54$ years old } \\
\hline Rosstat & 88.4 & 83.6 & 79.0 & 77.2 & 76.8 \\
\hline $\begin{array}{c}\text { Rosstat } \\
\text { (not accounting for } \\
\text { migration) }\end{array}$ & 88.4 & 82.6 & 77.0 & 74.1 & 72.3 \\
\hline
\end{tabular}

Thus, the forecast indicates particularly significant changes in the number of individual age groups and the quantitative ratios between them in the period from 2010 to 2030. These changes will have a significant impact on socio-economic development, affect the number of employees, students, and consumers of various kinds of goods and services, including the need to account for this situation in the development of infrastructure of sports facilities and the types of sports and healthcare services for the population.

\subsection{Forecasting Methods}

More precise planning of the development of sports facilities infrastructure and the types of sports and healthcare services for the population requires forecasting the number and structure of the population for each municipality, as the administrative and territorial structure of Russia on its vast territory includes about 21 thousand municipalities with significantly varying population, social structures, and needs and opportunities to engage in particular types of sport.

To make a forecast, it is necessary to refer to the methods for calculating these indicators. Modern demographic statistics has developed several methods for population forecasting that have different accuracy and are based on different models. The whole variety of population forecasting methods can be divided into two main directions - formalized and expert.

The expert approach is based on the prediction of processes that cannot be described by means of the mathematical apparatus due to the nature of the information or the lack of information base.
The formalized approach, considered to be of high accuracy and reliability, is represented by a wide range of statistical methods. These methods are widely used and have a relatively high degree of forecast reliability.

Depending on the information base, it is possible to distinguish between three groups of statistical methods for predicting population dynamics:

- projections based on retrospective population analysis;

- projections based on the indicators of the natural and mechanical dynamics of the population;

- projections based on the simulation of a series of dynamics.

Based on the above, it is possible to deploy any of the aforementioned methodologies for predicting the size and structure of the population of a municipality in each particular case.

\section{Results}

\subsection{Traditional Approach}

The formation of a system of motivation of citizens for a healthy lifestyle and the creation of the corresponding conditions in a municipality calls for consideration of several parameters. The first one is the type of municipality derived from other parameters: population, the natural, geographical, and climatic conditions, traditions, financial opportunities, and so on. The number of various types of municipalities in Russia is presented in Table 4. 
Table 4.

\begin{tabular}{|c|c|c|c|c|c|c|c|c|c|}
\hline & \multicolumn{9}{|c|}{ Number of municipalities by constituent entities of the Russian Federation as of January 1, 2020} \\
\hline & \multirow[b]{2}{*}{ Total } & \multicolumn{8}{|c|}{ including } \\
\hline & & $\begin{array}{c}\text { Municipal } \\
\text { district }\end{array}$ & $\begin{array}{c}\text { Municipal } \\
\text { okrug }\end{array}$ & $\begin{array}{l}\text { Urban } \\
\text { okrug }\end{array}$ & $\begin{array}{c}\text { Urban } \\
\text { okrug with } \\
\text { intra-urban } \\
\text { division }\end{array}$ & $\begin{array}{l}\text { Intra- } \\
\text { urban } \\
\text { district }\end{array}$ & $\begin{array}{c}\text { Intra-urban } \\
\text { territory } \\
\text { (intra-urban } \\
\text { municipal } \\
\text { formation) of a } \\
\text { federal city } \\
\end{array}$ & $\begin{array}{c}\text { Urban } \\
\text { settlement }\end{array}$ & $\begin{array}{c}\text { Rural } \\
\text { settlement }\end{array}$ \\
\hline A & 1 & 2 & 3 & 4 & 5 & 6 & 7 & 8 & 9 \\
\hline $\begin{array}{c}\text { Russian } \\
\text { Federation }\end{array}$ & 20,846 & 1,673 & 33 & 632 & 3 & 19 & 267 & 1,398 & 16,821 \\
\hline
\end{tabular}

Table 5. The population of Russia, urban okrugs, municipal districts, urban and rural settlements

\begin{tabular}{|c|c|c|c|c|c|}
\hline & \multirow{2}{*}{ Men and women } & \multirow{2}{*}{ Men } & \multirow{2}{*}{ Women } & \multicolumn{2}{|c|}{ In the total population, in \% } \\
\cline { 4 - 6 } & & & & men & women \\
\hline Russian Federation & $142,856,536$ & $66,046,579$ & $76,809,957$ & 46.2 & 53.8 \\
\hline Urban population & $105,313,773$ & $48,117,546$ & $57,196,227$ & 45.7 & 54.3 \\
\hline Rural population & $37,542,763$ & $17,929,033$ & $19,613,730$ & 47.8 & 52.2 \\
\hline
\end{tabular}

Table 6. Increase in the number of citizens of the Russian Federation systematically engaged in physical culture and sports

\begin{tabular}{|c|c|c|c|c|c|}
\hline Indicator & 2018 & 2019 & $+/-$ & 2024 & 2030 \\
\hline $\begin{array}{l}\text { Proportion and number of citizens of the Russian Federation } \\
\text { systematically engaged in physical culture and sports, aged } \\
\text { 3-79 years old }\end{array}$ & $\begin{array}{l}39.8 \% \\
(54.2 \mathrm{~m} . \\
\text { people })\end{array}$ & $\begin{array}{l}43.0 \% \\
(58.5 \mathrm{~m} . \\
\text { people })\end{array}$ & $\begin{array}{c}+3.2 \%(+4.3 \\
\text { m. people })\end{array}$ & $55 \%$ & $70 \%$ \\
\hline $\begin{array}{l}\text { Proportion and number of children and youth (3-29 years old) } \\
\text { systematically engaged in physical culture and sports }\end{array}$ & $\begin{array}{l}81.2 \% \\
(37.0 \mathrm{~m} . \\
\text { people) }\end{array}$ & $\begin{array}{l}83.9 \% \\
(37.8 \mathrm{~m} . \\
\text { people })\end{array}$ & $\begin{array}{l}+2.7 \%(+0.7 \\
\text { m. people) }\end{array}$ & $86 \%$ & \\
\hline $\begin{array}{l}\text { Proportion and number of middle-aged citizens (30-54 years } \\
\text { old (women), 30-59 years old (men) systematically engaged } \\
\text { in physical culture and sports }\end{array}$ & $\begin{array}{c}24.9 \% \\
(14.5 \mathrm{~m} . \\
\text { people })\end{array}$ & $\begin{array}{c}29.1 \% \\
(16.9 \mathrm{~m} . \\
\text { people) }\end{array}$ & $\begin{array}{c}+4.2 \%(+2.4 \\
\text { m. people })\end{array}$ & $52 \%$ & \\
\hline $\begin{array}{c}\text { Proportion and number of senior citizens (55-79 years old } \\
\text { (women), 60-79 years old (men) systematically engaged in } \\
\text { physical culture and sports }\end{array}$ & $\begin{array}{l}8.2 \% \\
(2.6 \mathrm{~m} . \\
\text { people })\end{array}$ & $\begin{array}{l}11.7 \% \\
(3.8 \mathrm{~m} . \\
\text { people })\end{array}$ & $\begin{array}{l}+3.5 \%(+1.2 \\
\text { m. people })\end{array}$ & $22 \%$ & \\
\hline
\end{tabular}

This diversity of municipalities undoubtedly reflects the population size, habits, and priorities in the choice of a particular type of sport. The ratio of the urban and rural population by total number and gender is presented in Table 5.

Important characteristics of a municipality include not only the population size but also population density, as it greatly affects the formation and development of the infrastructure of the municipality, including sports facilities.

In accordance with the Decree of the President of the Russian Federation, a significant number of measures aimed at providing the population with sports facilities have been developed. These measures account for the parameter of the age of citizens. To solve the objectives established as part of the earlier Decree of the President of the Russian Federation No. 204 "On the national goals and strategic objectives of the development of the Russian Federation for the period up to 2024", the Federal Project "Strengthening Public Health" was developed. The project defines the objectives for the subjects of the Russian Federation to ensure the introduction of a new model for the organization and functioning of public health centers.

Along with the Federal Project "Strengthening Public Health", the Federal Project "Sport as a Standard of Life" was introduced. The goal of the Federal Project "Sport as a Standard of Life" is to bring the percentage of citizens systematically engaged in physical culture and sports up to $55 \%$ by 2024 by means of motivating the population and activating mass sports work at all levels and in the corporate environment (Table 6).

Achievement of the goal is provided by its decomposition in the Passport of the Federal Project into the following main indicators in three age groups:

- the share of children and young people (3-29 years old) in the total number of children and young people (in \%);

- the share of middle-aged citizens (women: 30-54 years old; men: 30-59 years old) in the total number of middle-aged citizens (in \%); 
- the share of senior citizens (women: 55-79 years old; men: 60-79 years old) in the total number of senior citizens (in \%).

According to the Federal Project "Sport as a Standard of Life", physical culture and sports have to be systematically practiced by 3 to 5 million people annually in addition to the forecasted number of the previous year.

However, considering the new objective established in the Decree of the President of the Russian Federation No. 474 "On the national development goals of the Russian Federation for the period up to 2030", these rates should be revised, as by 2030 , the proportion of citizens systematically engaged in physical culture and sports has to rise up to $70 \%$ (Table 6).

\subsection{Innovative Approach}

Meeting the established objective calls for developing new approaches. Undoubtedly, the size and density of population on the territory of a municipality are significant, but they are not enough to determine the structure and number of sports facilities. Assessment of citizens' health allows identifying the nature and specialization of sports facilities. After all, the state of citizens' health is not uniform even within a single age and gender group. Therefore, we consider it necessary to account for this indicator. This goal requires the local authorities of each municipality to introduce the "Municipality Population Health Passport".

The municipality population health passport implies a thorough analysis of the state of citizens' health and the identification of three groups within each age subgroup:

- D-1 group - the category of completely healthy citizens;

- D-2 group - the category of citizens with minor ailments that do not prohibit them from engaging in physical education and sports;

- D-3 group - the category of citizens with quite serious illnesses.

Under this approach, it is possible to create a classification of sports facilities intended for each of the 9 population groups stratified both by age and the state of health (the suggested group titles are notional and are subject to change):

1. "Group A" - the share of children and young people (3-29 years old) belonging to the D-1 health group in the total population $(\mathrm{N})$.

(A $\times 100 \%$ ) $/ \mathrm{N}=\%$ (children and youth of D-1 health group)

2. "Group B" - the share of children and young people (3-29 years old) belonging to the D-2 health group in the total population $(\mathrm{N})$.

(B x 100\%) $/ \mathrm{N}=\%$ (children and youth of D-2 health group)
3. "Group C" - the share of children and young people (3-29 years old) belonging to the D-3 health group in the total population $(\mathrm{N})$.

(C x 100\%) / $\mathrm{N}=\%$ (children and youth of D-3 health group)

4. "Group D" - the share of middle-aged citizens (women: 30-54 years old; men: 30-59 years old) belonging to the $\mathrm{D}-1$ health group in the total population $(\mathrm{N})$.

(D x 100\%) / $\mathrm{N}=\%$ (middle-aged citizens of $\mathrm{D}-1$ health group)

5. "Group E" - the share of middle-aged citizens (women: 30-54 years old; men: 30-59 years old) belonging to the D-2 health group in the total population $(\mathrm{N})$.

(E x 100\%) / $\mathrm{N}=\%$ (middle-aged citizens of D-2 health group)

6. "Group F" - the share of middle-aged citizens (women: 30-54 years old; men: 30-59 years old) belonging to the D-3 health group in the total population $(\mathrm{N})$.

(F $\times 100 \%$ ) / $\mathrm{N}=\%$ (middle-aged citizens of D-3 health group)

7. "Group G" - the share of senior citizens (women: 55-79 years old; men: 60-79 years old) belonging to the D-1 health group in the total population $(\mathrm{N})$.

( $\mathrm{G} \times 100 \%) / \mathrm{N}=\%$ (senior citizens of $\mathrm{D}-1$ health group)

8. "Group H" - the share of senior citizens (women: 55-79 years old; men: 60-79 years old) belonging to the D-2 health group in the total population $(\mathrm{N})$.

( $\mathrm{H} \times 100 \%) / \mathrm{N}=\%$ (senior citizens of $\mathrm{D}-2$ health group)

9. "Group I" - the share of senior citizens (women: 55-79 years old; men: 60-79 years old) belonging to the D-3 health group in the total population $(\mathrm{N})$.

(I x 100\%) / N = \% (senior citizens of D-3 health group)

These data allow the local authorities of a municipality to precisely determine the number and kinds of sports facilities needed on their territory to provide all 9 population groups the opportunity to engage in certain types of sports. The common stereotype that the money allocated as part of the National Project has to be invested in building an expensive stadium without considering the demand for it often results in such a stadium ending up abandoned and deteriorating. However, the consideration of the opinion and capabilities of social groups in accordance with the "Municipality Population Health Passport" allows using the allocated finances with greater efficiency and payoff providing virtually all citizens of a municipality with the opportunity to choose the type of sports activity suiting their health and age. 


\section{Discussion}

\subsection{The Objectives of Local Authorities}

Article 9 of the Federal Law of December 4, 2007, No. 329-FZ (as revised on October 2, 2019) "On Physical Culture and Sports in the Russian Federation" [9] identifies the "Powers of local authorities in the field of physical culture and sports".

This law describes quite a large range of powers of local authorities to solve the local issues of ensuring the necessary conditions for the development of physical culture and sports on the territory of municipalities [10] and defines the main tasks and directions of the development of physical culture and sports taking into account the local conditions and opportunities. However, supplementing this list of powers with a compulsory requirement to develop a "Municipality Population Health Passport" would increase the efficiency and focus of all work in this direction.

As a part of implementing the Federal Project, local authorities are undoubtedly assigned extremely challenging tasks associated with improving sports infrastructure and creating new facilities for physical culture and mass sports activities both in organized and individual form. This work requires a scientific social-engineering approach to making managerial decisions [11]. All municipal districts must be equipped with small sports fields. This implies using standard solutions that allow minimizing both time and financial costs. The population exceptionally positively responded to the organization of freely accessible areas with various simulators that previously could only be used in fitness clubs with quite expensive subscriptions.

Such small training areas can be built both in urban yards and parks [12] and in rural areas. They attract citizens both due to the territorial accessibility and because their use is free of charge.

Another quite extensive field of work for local authorities is the organization of a large-scale information and communication campaign aimed at the formation of a new attitude to physical development and mass sports, the creation of a system of individual motivation of citizens for regular physical activity and sports, informing them about physical culture and sports events and the activities of physical culture and sports organizations, attracting various categories of citizens, including people of middle and older age groups, to participate in such mass annual events as the All-Russian Running Day "Cross Country", the All-Russian Walking Day, the All-Russian mass skiing race "Ski Track of Russia", and the All-Russian competitions in orienteering "Russian Azimuth". The coverage of events from top sports and the successful performance of Russian athletes at major international sporting events is also of great importance, as it promotes a sporting lifestyle among all population groups, especially children and young people. The main channels of the information and communication campaign should be the print and electronic media, as well as social networks. Social networks are particularly popular. The core of the active audience is people aged from 18 to 34 years old, with a monthly audience of 54.6 million people, half of whom are publicly active. They create more than 40 million posts per day. Authors creating public content are contributing to social media becoming an increasingly relevant indicator of public sentiment.

Another extremely important task for municipal authorities is to create a system of personnel support for the implementation of the Federal Project. For this purpose, the need for local organizers of sports and mass activities, as well as for coaches to master additional professional programs must be identified [13].

For this purpose, the Russian Ministry of Health, in developing a new model for the organization and operation of public health centers, provides for:

- the training of specialists in the field of public health;

- the creation of departments and faculties of public health in medical schools;

- the inclusion of full-time public health specialist units in the staff schedule of public authorities of the subjects of the Russian Federation, as well as local authorities.

These measures will contribute to the creation of a system of personnel support for the implementation of the federal projects aimed at the development of physical culture and sport among the population, strengthening the physical health of citizens, and the formation of a healthy lifestyle.

\subsection{The Development of Positive Practices}

An important source for the effective development of physical education and sport among the population of municipalities is the exchange of experience and examples of good practice. This work is being actively implemented by the All-National Association of Territorial Public Self-Governance (ANATPSG). Studying positive practices, disseminating the experience of municipalities, holding various contests to increase public activity and involvement in solving many local issues, holding national conferences on the key issues of municipal development, including the development of physical culture and sports - this is only part of the work carried out by the ANATPSG.

At the initiative of the Federal Expert Council on Local Self-Governance (FEC) as part of ANATPSG, together with such organizations as the League of Health of the Nation, the Union of Russian Cities, the Russian Social Movement "Family of the Fatherland", the All-Russian Meeting with regions, municipal councils, and local communities on public health, health promotion, physical education, and mass sports was held in Moscow on July 
14, 2021 [14]. It was attended by about a thousand delegates from 72 subjects of the Russian Federation. The meeting was held within the framework of the All-Russian Forum "Health of the Nation - the Basis of Russia's Prosperity" [15] organized by the All-Russian Public Organization "League of Nation's Health" and the Ministry of Health of the Russian Federation. The objective of the forum was to accumulate the best practices and demonstrate successful regional and municipal practices in the implementation of national projects "Health", "Demography", "Education", and "Culture", discuss the effectiveness of measures adopted at all levels to strengthen public health, change citizens' attitudes to their health, and increase their responsibility for its condition.

The meeting presented a draft of the Declaration on Health covering the three components of health: spiritual, mental, and bodily. It notes that a culture of healthy life must become predominant in every person, family, society, and state. The development of public health and mass sport, involvement of young people in sport, and implementation of public health projects were presented as national priorities of Russian state policy. There was great interest in the comprehensive program "Healthy Municipality" for increasing the physical activity of citizens presented by the Vice-President of the All-Russian Public Organization "League of Nation's Health". The first vice-president of the All-Russian Swimming Federation suggested the creation and promotion of mobile swimming complexes to organize universal swimming lessons for the population. The speakers paid great attention to involving and motivating people with disabilities for physical culture and mass sports.

The Moscow Department of Sports is successfully implementing the "Moscow Longevity" project that has gained great popularity among senior citizens. The project includes Nordic walking and other sports that are feasible for this age group. This experiment has significantly increased the vitality of senior citizens, formed a positive perception of an active lifestyle, improved the quality of life, and promoted the development of certain forms of social communication [16]. This experience deserves the widest dissemination in other regions. Such involvement of the older generation in sports has a double benefit: it not only strengthens the physical condition of citizens but also provides them with an opportunity to communicate, which is almost lacking for many people at this age. Positive emotions from communicating with peers in sports have a great impact on the rejuvenation and recovery of the human body.

Iu. D. Ovchinnikov proposes a broad introduction of health schools for the population as a new format of sports culture development. The researcher is assured that the new format of systemic health improvement can be Irina Slutskaia's Scandinavian walking schools [17]. Having thoroughly studied the sports events and information materials about the schools of Nordic Walking training by the method of I.M. Slutskaia, the researcher proposes the instructors and coaches of municipal sports institutions to take an additional training course "Nordic Walking in Medical Rehabilitation". This type of activity would be useful for municipal institutions of various profiles as a new educational technology for the development of practice-oriented education in health preservation for the population.

Another area of actively developing projects currently initiated and financially supported in Russia is an extensive state program for the development of domestic tourism as a kind of physical culture and sport that improves the health of citizens and allows them to learn more about the features, culture, and traditions of their country [18].

Today, many playgrounds are being built with slides, swings, etc., i.e. for little children. Mothers walking on these playgrounds with their children are forced to stand, or at best, sit on a bench for the entire walk. It would be very appropriate to build exercise equipment for mothers in these areas. A walk with a child combined with sports would be of great benefit to a young woman and would help her recover from childbirth and improve her health.

Bicycles and scooters are popular and are rapidly being introduced in both urban and rural life. The creation of conditions for their use and the creation of special paths will make this sport even more attractive.

In winter, to increase the attractiveness of skiing, it is worth adopting the experience of Siberian regions and equip lighted ski tracks, since the daylight hours during this period are short, and in the evening after school or work, those who prefer this sport would be able to do it.

It is expedient to refer to the experience of the Soviet period when every enterprise necessarily conducted industrial gymnastics and the morning on the radio and television began with the words: "Let's start morning gymnastics". The modern days demonstrate positive examples in this regard, such as the return of the GTO ("Ready for Labor and Defense") norms. An article by A.Iu. Kachanovskii who studied archival materials of physical education in the USSR describes the positive practice of the All-Union sports complex "Ready for Labor and Defense" that was adopted on March 11, 1931, and served as a basis of physical education of the population aged from 16 years old and older [19]. The GTO complex was a state system of program and evaluative norms and requirements for physical fitness for different population groups.

Modern researchers and practitioners in healthcare and sports actively discuss the creation of conditions for mass involvement in physical culture, as well as the formation of the healthy lifestyle of the population by means of organizing physical culture and sports work [20]. This issue is addressed by a substantial number of publications 
that can also serve as a source of popularization of positive practices and scientifically grounded recommendations.

\section{Conclusions}

The formation of a system of motivation of citizens for a healthy lifestyle is a state objective, however, as it is implemented in specific territories, the role of local authorities in this work is difficult to overestimate [21]. The state currently allocates major funding for the implementation of the National Project "Health". Nevertheless, it is a difficult task to channel these funds to building new sports facilities and creating the conditions necessary for engaging all social groups populating the given territory in physical culture and sports. This task requires a thorough study of the social structure of each municipality, the creation of the "Municipality Population Health Passport", and the identification of the needs and interests of all 9 social groups proposed in the present study. Only this approach will help to motivate citizens to do sports and choose the kind of physical activity that suits their desires and abilities.

Such purposeful work calls for trained personnel both for the sphere of sports and healthcare and for the authorities. In contemporary Russia, decisions have been made to open new specialties and create departments and faculties of public health.

Using modern information technology, the campaign to promote the sporting lifestyle as fashionable and attractive was launched. For instance, L.B. Sholokhova notes that the presence of gyms, swimming pools, stadiums, and other sports facilities is of primary importance in the organization of physical culture and recreational activities. Unfortunately, the sports material and technical base are not always used effectively. The author believes that one of the reasons for this reality lies in the lack of promotion of the values of physical culture and sports. In this regard, L.B. Shorokhova proposes the creation of a management structure for the promotion of physical culture and sports [22]. Outreach is becoming an effective form of work, as attendance at fitness clubs, swimming pools, exercise classes at the gym, active use of bicycles and scooters not only for sports, but as a means of transportation, having a good physical shape, and reducing excess weight are all clear signs of progress on the way towards a healthy lifestyle, the population's gradual acceptance of the change in their passive lifestyle, and the sporting activities growing to become a norm of life [23,24].

\section{REFERENCES}

[1] Decree of the President of the Russian Federation No. 474
"On the national development goals of the Russian Federation for the period up to 2030", July 21, 2020, http://publication.pravo.gov.ru/Document/View/00012020 07210012

[2] Decree of the President of the Russian Federation No. 204 "On the national goals and strategic objectives of the development of the Russian Federation for the period up to 2024", May 7, 2018, http://publication.pravo.gov.ru/Docu ment/View/0001201805070038

[3] Rosstat. Predpolozhitelnaia chislennost naseleniia Rossiiskoi Federatsii do 2030 goda [Estimated Population Size of the Russian Federation until 2030]. Statistical Bulletin, Federal State Statistics Service, Moscow, 2010.

[4] UN Population Division. World Population Prospects: the 2010 Revision, 2011, http://www.unpopulation.org/

[5] US Census Bureau, 2010, http://www.census.gov/ipc/ww w/idb/

[6] The National Institute of Population and Social Security Research of Japan, 2018, http://www.ipss.go.jp/site-ad/ind ex_english/population-e.html

[7] A. G. Vishnevskii. Naselenie Rossii 2007: piatnadtsatyi ezhegodnyi demograficheskii doklad [The population of Russia 2007: fifteenth annual demographic report], Higher School of Economics, Moscow, 2009.

[8] K. E. Laikam (ed.). Trud i zaniatost v Rossii 2009: stat. sb. [Labor and employment in Russia 2009: statistical digest], Publishing House of the Federal State Statistics Service, Moscow, 2009, p. 27.

[9] State Duma of the Federal Assembly of the Russian Federation. Federal Law No. 329-FZ "On Physical Culture and Sports in the Russian Federation", December 4, 2007 (as revised on October 2, 2019), http://www.kremlin.ru/act s/bank/26631

[10] T. A. Evstratova, E. E. Kabanova, E. A. Vetrova, O. A. Kulikova, O. A. Kolosova. The image of municipalities, International Journal of Criminology and Sociology, No.9, 2711-2717, 2020.

[11] O. A. Urzha. Social engineering - as methodology of management activity, Sotsiologicheskie Issledovaniya, No.10, 87-96, 2017. DOI: 10.7868/S0132162517100099

[12] O. A. Urzha, T. A. Evstratova, V. I. Kataeva. A project to improve the profitability of the use of park areas (evidence from Zaryadye Park, Moscow City, Russia), International Journal of Recent Technology and Engineering, Vol.8, No.3, 4402-4406, 2019. DOI: 10.35940/ijrte.C5531.098319

[13] G. Z. Aronov. Organizatsionno-pedagogicheskoe upravlenie massovoi fizicheskoi kulturoi v munitsipalnom obrazovanii [Organizational and pedagogical management of mass physical education in a municipality]: abstract dis.... candidate of pedagogical sciences: 13.00.04, National State University of Physical Education, Sports and Health named after P.F. Lesgaft, Saint Petersburg, Russia, 2003, 24 p.

[14] All-Russian meeting on the formation of public health and mass sports, July 14, 2021, https://youtu.be/axGpKmmagrs

[15] All-Russian Forum "Health of the Nation - the Basis of Russia's Prosperity”, 2021, http://znopr.ru/ 
[16] Ministry of Sport of the Russian Federation. Sbornik materialov Vserossiiskoi nauchno-prakticheskoi konferentsii "Luchshie modeli organizatsii massovoi fizkulturno-sportivnoi raboty sredi tselevykh vozrastnykh i sotsialnykh grupp naseleniia" [Collection of materials of the All-Russian Scientific and Practical Conference "The best models of mass physical culture and sports work among the target age and social groups"], Moscow, 2020, $326 \mathrm{p}$.

[17] Iu. D. Ovchinnikov, V. A. Pikalina. Ozdorovitelnye shkoly dlia naseleniia: novyi format razvitiia [Recreational schools for the population: a new format of development], Business. Education. Law, Vol.1, No.50, 421-425, 2020.

[18] O. A. Urzha, N. I. Mikhoparov, E. M. Kryukova, V. Yu. Shalashnikova, Yu. O. Sulyagina. Sociological analysis of domestic tourism in the Chuvash Republic: current status, existing problems and solution, Journal of Environmental Management and Tourism, Vol.8, No.8(24), 1504-1517, 2017.

[19] A. Iu. Kachanovskii. Otechestvennyi opyt vovlecheniia molodezhi $\mathrm{v}$ massovye zaniatiia fizkulturoi i sportom [Domestic experience of involving young people in mass physical fitness and sports], Journal of Secondary Vocational Education, No.4, 60-61, 2012.

[20] A. S. Iakovlev, M. A. Naumova, E. A. Kalieva. K voprosu o variativnosti planirovaniia $\mathrm{i}$ organizatsii fizkulturno-sportivnoi raboty po mestu zhitelstva [On the variability of planning and organization of physical culture and sports work at the place of residence], Theory and Practice of Physical Culture, No.12, 13-15, 2015.

[21] A. Iu. Bliznevskii. Stimuliruiushchaia sistema otsenki fizkulturno-ozdorovitelnoi deiatelnosti munitsipalnykh obrazovanii kak fundament ee razvitiia $\mathrm{v}$ subekte RF [Incentive system of evaluation of physical culture and fitness activities of municipalities as a foundation for its development in the subject of the Russian Federation], Scientific notes of St. Petersburg State University of physical culture of P.F. Lesgaft, Vol.7, No.113, 27-34, 2014.

[22] L. B. Shorokhova. Ekspertnaia otsenka vozmozhnosti sozdaniia struktury upravleniia propagandoi fizicheskoi kultury i sporta na munitsipalnom urovne [Expert evaluation of the possibility of creating a management structure for the promotion of physical culture and sport at the municipal level], Omsk Scientific Bulletin, Vol.6, No.74, 145-148, 2008.

[23] I. Turski, H. Mashika, T. Tkachenko, M. Khmara, I. Komarnitskyi, M. Oliinyk. Medical Tourism: Analysis of the State of International Tourism and Prospects for Domestic Development, Universal Journal of Public Health, Vol.9, No.2, 27-34, 2021. DOI: 10.13189/ujph.2021.090201

[24] M. Sasaki, M. Parianos, S. Rahman. Top Five Cancer Health Disparities in Florida: Race, Ethnicity, Geographic Location and Socio-Economic Predictors, Universal Journal of Public Health, Vol.9, No.2, 35-50, 2021. DOI: 10.13189/ujph.2021.090202 